\title{
Implementation of Diversity Management Contents into the Curricula of Higher Education Institutions in Western Balkans Countries
}

Summary: The present-day globalised world is becoming more and more diverse because of migrations and other socioeconomic changes in society. Due to the deep-rooted stereotypes and negative attitude towards "differentness", discrimination based on diversity is becoming more and more common. Our society has become multicultural and multi-ethnic, which is something that educational institutions must be aware of; hence, the traditional learning contents in the curricula of individual study programmes must be modified. We must discuss the importance of diversity, the various types, forms and consequences of diversity, the causes behind it, and the influence of higher education institutions on the acceptance and promotion of diversity if we wish to encourage students to develop a culture, values and attitudes for a positive evaluation of diversity. By doing so, we will be able to achieve sustainable development at higher education institutions, which requires observance of the laws of the natural environment and of the cultural relationships within society, as well as their balance, since education for sustainable development motivates, provides knowledge, creates new paths toward a more just and equal world, and enables learning that changes our understanding of the environment, of an individual's habits, actions and lifestyles in order to attain a higher quality of living for the present and future generations.

The study conducted among 1560 higher education teachers at higher education institutions in the Western Balkan countries has shown that the curricula of the subjects they teach mostly include those dimensions of diversity that affect an individual's self-image. Moreover, they have established that regardless of their study course, students should be taught the differences among individuals regarding their level of education, esteem, work experience and position at the workplace. They have listed the case method, discussion method and problem-solving method as the most suitable methods for teaching diversity management. As one of the most important learning objectives in teaching diversity, they have emphasised understanding, raising the awareness of students of diversity, and familiarising them with the importance of incorporating diversity into everyday life.

Key words: teaching diversity management, higher education institutions, sustainable development, curriculum, higher education teachers, students.

1 jasmina.starc@guest.arnes.si Copyright $\odot 2016$ by the authors, licensee Teacher Education Faculty University of Belgrade, SERBIA.

This is an open access article distributed under the terms of the Creative Commons Attribution License (CC BY 4.0) (https://creativecommons.org/licenses/by/4.0/), which permits unrestricted use, distribution, and reproduction in any medium, provided the original paper is accurately cited. 


\section{Introduction}

In today's world, diversity is gaining a new dimension, meaning and purpose. Casse (2016) points out that it is characteristic of today's diversity that there is more information available than ever before; what was once agreed on is undergoing transformation faster (the meaning of things is changing so rapidly that the human brain cannot make sense of it); and that new differences are in fact brought about by young people, by women all over the world, and by countries too. Perhaps the main challenge that we are facing at the start of a new century is not the excess of diversity, but its regression and progression of equality in all of the decisive human dimensions. Globalisation affects the work patterns of employees in the higher education sector, since higher education teachers are encountering extremely diverse students in their work (Johnson, 2016), who may present great potential for achieving progress, and denote creativity and productivity of the study group; but simultaneously they are creating utterly specific situations, as well as conflicts and challenges (Rozman, 2016:16).

We must be aware of the fact that students differ from one another by (Gardenswartz and Rowe, 2003): personality; primary factors (gender, age, nationality); secondary factors (education, religion, language/accent, appearance, geographic location); organisational factors (the role of an individual at a college or faculty, his/her academic achievement); and cultural factors (attitude towards authority, personal space, attitude towards competitiveness, body language). More and more adolescents with culturally diverse backgrounds are entering the education system. These cultural differences are also evident among members of different social classes and ethnic groups, and among representatives of different genders, sexual orientations, lifestyles and religious communities (Košak, 2010).

In the higher education system, diversity management employs an individual and organisational approach. The individual approach to diver- sity management comprises two interdependent directions: learning and empathy. The first is based on gaining genuine or simultaneous experiences, while the latter is based on the ability to understand feelings and emotions (Treven, 2001). Empathy is closely connected with the strategy of individual learning. It refers to the susceptibility of an individual to the feelings, needs and concerns of others. It can also be defined as the ability to put oneself in someone else's shoes and view the world from another perspective (Harzing and Pinnington, 2011). Empathy is very important for diversity management (West-Burnham, 2010:15), since the people coming from diverse groups believe that they are the only ones who know the kind of problems they are encountering, and that they are the only ones who understand these problems. The fact is that educational institutions are not ready for diversity management and must therefore create a vision that would explain the actual meaning of the diversity of their employees and students, what diversity is to them and the advantages and benefits that it would generate for higher education institutions. It is also important that the management of the higher education institutions (director, chancellor, dean, deputy deans) actively participates, providing support to diversity management and setting an example for others with its activity in this field (Gjerdrum Pedersenet al., 2011).

Striving towards equality and fairness is one of the important principles of education. Of course, the realisation of this principle is greatly limited due to various external factors, which the higher education institution can only partially compensate for. Milharčič Hladnik (2003:49) mentions three predominant models of interpreting (in)equality in education: (1) meritocratic model: emphasises the inherited abilities, which the family, school (educational) and working environment only strengthen further, thus making any rebalancing measures pointless and inefficient; (2) class model: interprets educational inequalities as a result of material and cultural social differences, which can be eliminat- 
ed or reduced, hence various rebalancing measures would be sensible; and the (3) traditional model: considers both the inherited properties and the properties acquired in the social environment to be important, whereas the reference framework is determined by the dominant culture. Each model understands and structures the most common types of educational inequalities in its own way: the inequality of the student's origin, the inequality of academic abilities, and the inequality of the academic environment (teaching methods, equipment in lecture halls, the reputation and standing of the higher education institution). If a higher education institution wishes to be fair, it must take into account the diversity of its students. Peček and Lesar (2006:12) stress that the fairness of every institution, including a higher education institution, lies in its power to recognise whether its processes and activities are equally accessible to all who are a part of it. For example, underprivileged students, who may be entitled to a greater amount of social benefits due to poorer initial opportunities, should be treated differently, and consequently, privileged students must likewise be treated accordingly if that would improve the situation of the underprivileged ones.

In the past decade, we have witnessed great changes connected with sustainable development in the field of education, since higher education institutions are responsible for the development of the intercultural and global competences of graduates, which will enable their successful work in the local, national and global environment (Bâc, 2008). Higher education institutions are educating a great number of people who will one day be leading, developing, managing, educating, working, and influencing society and institutions (Cortese, 2003). Because it is essential that each individual in modern society is capable of acting accordingly in a multicultural, multilingual and international environment, and is familiar with the cultural specifics, higher education institutions must provide quality implementation of an internationalised curriculum, above all the systematic incorporation of the intercultur- al dimension into all study courses and disciplines in all study programmes and fields. Higher education bears great responsibility for shaping and expressing the ethical and technological knowledge, which is needed to ensure the quality of life of future generations (Wright, 2006). Sustainable development enables the satisfying of the needs of present generations, while simultaneously not limiting the possibilities of future generations for satisfying their own needs to at least the same extent. The realisation of sustainable development requires the continuous assessment of practice and activities, of the formation of roles, attitudes, mindsets and evaluation methods, which includes the continuous evaluation of educational practices (Ličen, 2015) that are reflected in the definition of sustainable development as a management method which satisfies the needs of contemporary society without diminishing the possibilities of future generations, while keeping the ecological, economic and social aspects in equilibrium (Anko et al., 2009: 55), which is based on three hypotheses: (1) the environment has value, (2) long-termness and (3) equality among people and generations. Education for sustainable development focuses on social cohesion, on problems caused by conflicts between social and cultural goals, and on cultural and social diversity; its activities are directed toward motivating for a change in an individual's lifestyle, stemming from personal convictions, and encourage actions that provide an opportunity for developing moral criteria (Glavič and Kovačič Lukman, 2007). Sustainable development in education requires systemic thinking, learning and teaching, so that students can develop the intercultural, social and civic competences needed to successfully function and be employed in a global environment, and so that teachers can be suitably qualified for teaching culturally-mixed and diverse groups of students and function in an intercultural setting.

Diversity in education is primarily about recognising differences and respecting individuals, regardless of these differences, and, consequently, ensuring integration and equality. The notion of equal- 
ity does not merely refer to all human beings, but is also deeply rooted in the principle that each person is untouchable, which is founded on a right that not even the welfare of society as a whole can outweigh (Rawls, 1971, in West-Burnham, 2010:8). In their work, higher education teachers must be highly sensitive to and tolerant of all types of diversity. Reckless behaviour can quickly lead to generalised stereotypical judgements about students who stand out in any way. We must abide by the principle that teachers do not teach all students equally and that they do not work with all of them in the same way, but differently with different students.

The quality and functioning of the education system are connected with the transparency of society, with its characteristics, and with the broad consensus on the social image of the country. There is a binding transparency and commitment to integrative, fair and innovative social values within and without the education system (Pont et al., 2008:80), which means that: (1) the value of a human being must be respected, regardless of gender, age, religion, origin, beliefs and skills; (2) relationships between the teacher and a group or an individual student must be governed by fairness; (3) the basis for all social relationships is the respect for freedom, which is a person's core value; (4) a teacher accepts the student and endeavours to treat every individual equally; and that (5) fairness is accompanied by equality, avoidance of discrimination and bias, giving everyone a chance to be heard.

The higher education sector must be aware of the fact that the modern globalised world is becoming more and more diverse because of migrations and other socioeconomic changes. In principle, all of us, higher education teachers, must be aware of the fact that the diversity of students enriches us in all areas, and broadly speaking also in the field of culture, the functioning of society and, last but not least, in the fields of commerce, non-commercial activities and public administration, where our graduates become employed after finishing their studies.
Nevertheless, due to the deep-rooted stereotypes and the comeback of a negative attitude towards "differentness", discrimination based on diversity is becoming more and more common. This is surely a good reason to seriously consider modernising the curricula and the syllabi of courses and study programmes, and begin to raise awareness of diversity, starting with the higher education teachers, who must learn how to casually discuss diversity with their students. The curriculum - as some sort of a rational social consensus and an optimal method of education and of shaping the identity of the modern-day citizen - must take into account the many and diverse philosophical, social, technical, cultural and pedagogical experiences, knowledge and qualifications (Previšić, 2005:165). If we wish for graduates to become sensitive and open to people and social situations, develop communication skills in their local and international environment, respect non-discrimination and multiculturalism, and know and understand the developmental tendencies, differences and needs of individuals, we must switch from a closed curriculum to an open curriculum, which enables students and teachers to show initiative, spontaneous events in the teaching process, and creative behaviour of all participants in the process. It takes into account the hidden influences in education, which appear as some sort of equal co-teachers within a "hidden learning plan" and unplanned educational activities (Aronowitz and Giroux, 1991). It can be said that the source for shaping the curriculum is the thoughts of people about the values and goals, which are connected with what we students/graduates/citizens wish for in the future and how we can benefit from the educational process (Jurić, 2005:193). In order to function in this way, the higher education institutions and teachers must have relative autonomy.

Diversity management is likely to remain an add-on unless colleges and faculties do more to include this issue in their overall strategies, as well as in the day-to-day teaching and research activities: (a) First, a limited number of issues dominate the 
diversity agenda. In the future, it will be necessary to promote a broader perspective on diversity management. The question is, how do we ensure the diversity of diversity management teaching and research? It does not mean that issues, which have previously been prominent on the diversity agenda (for example gender), should be ignored and become back burner issues (Buchholtz and Carroll, 2009). Rather, diversity management should focus on raising awareness of the multiple aspects of the diversity concept that are relevant in today's society. (b) Secondly, it is relevant to discuss how diversity management becomes 'built-in' rather than 'bolt-on' to the existing courses and modules. The key question is, how do we integrate diversity management as part of the curriculum and teaching at all levels? Although diversity management content is widespread, it is necessary to implement teaching more intensively at graduate and postgraduate levels. Diversity management is typically part of a different course/module or an elective class. In order to stimulate the mainstreaming of diversity management, it is relevant to consider how much more comprehensively and co- herently teaching programmes can be designed. Integration of diversity management teaching in existing and new education programmes is an important factor in this effort (Plaschka and Welsch, 1990) (Figure 1). (c) Thirdly, teaching methods, materials and tools can be improved. The question is how do we develop innovative teaching methods and tools that will improve the quality of diversity management teaching at colleges and faculties? Today, diversity management is mainly taught using traditional teaching methods. It may be relevant to consider whether it is possible for institutions to collaborate and develop a high-quality teaching toolbox in diversity management.

Today, the resources in diversity management teaching seem to be spread all over the world with only limited knowledge sharing and dissemination. Better teaching materials would provide lecturers with more knowledge and expertise to design and implement innovative teaching programmes in diversity management that address all types of learning styles (Blenker et al., 2006) (Figure 2).

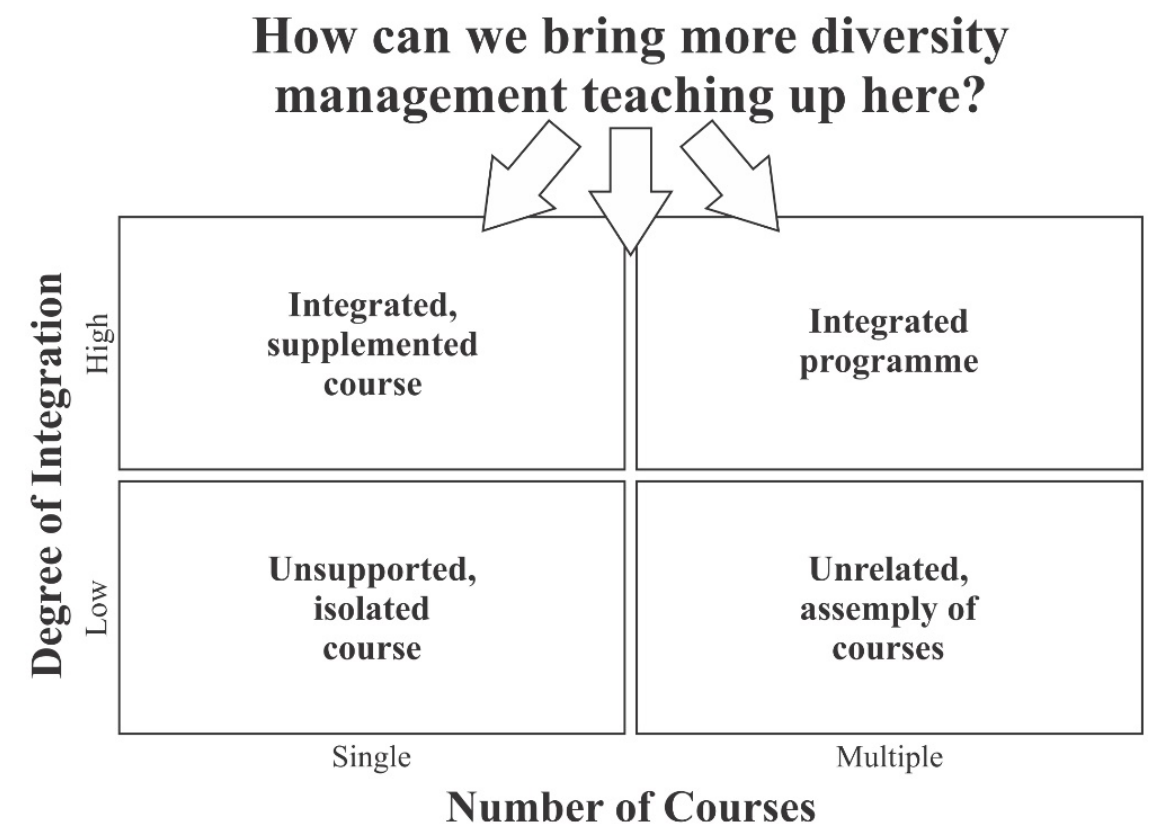

Figure 1. Towards integrated diversity management teaching (Plaschka and Welsch, 1990). 


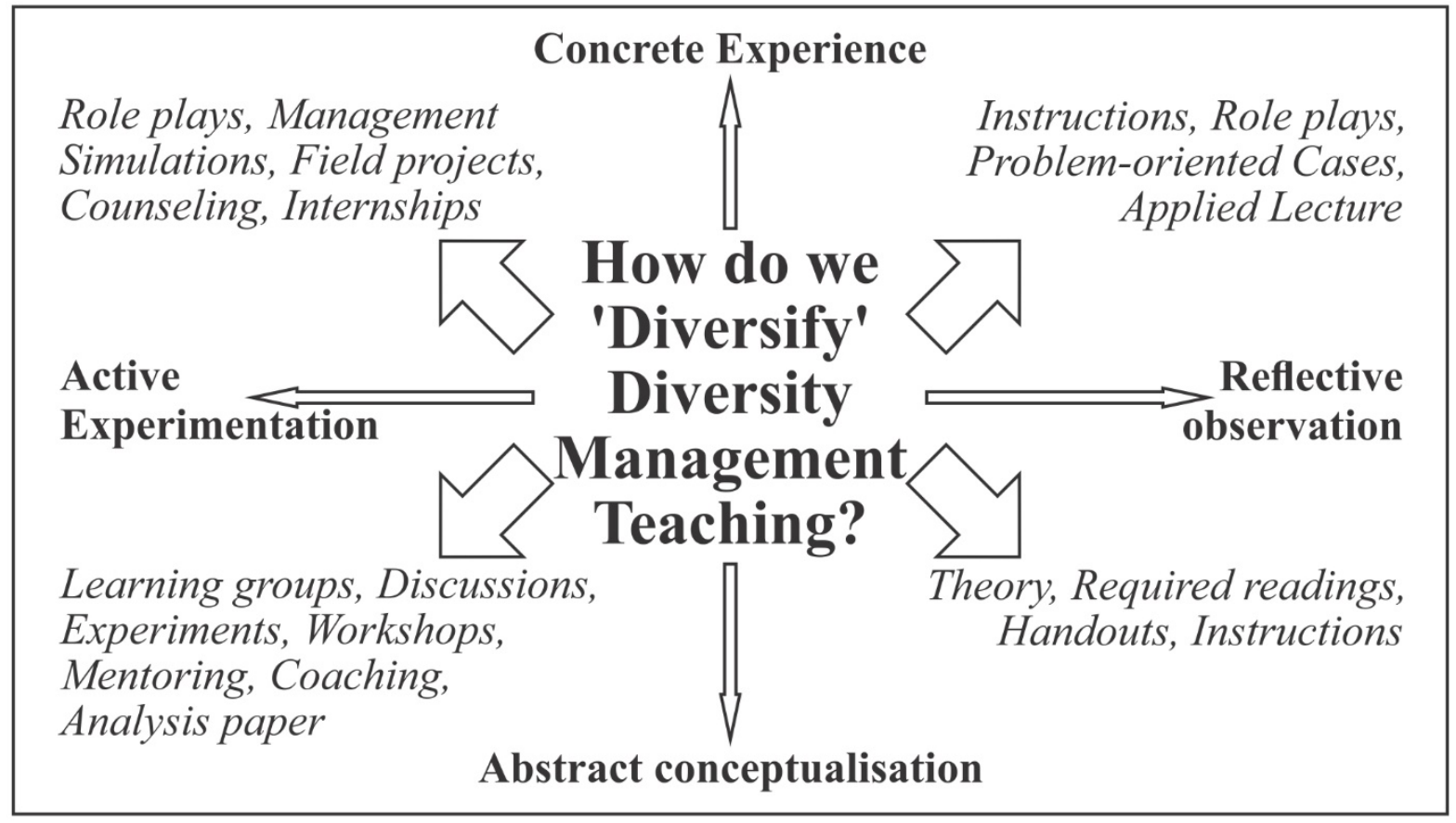

Figure 2. Diversity management and learning styles (Blenker et al., 2006).

(d) Finally, it is worth emphasising research in diversity management. The issue here concerns the possibility of moving diversity management up the research agenda. Whereas diversity management issues are taught at most colleges and faculties, research in this area seems to have a rather low priority. More research on diversity management will not only generate new knowledge but may have a spin-off effect on teaching activities. Increased focus on advanced research at the $\mathrm{PhD}$ level and academic exchange may be some of the initiatives to be considered in order to foster more research on diversity management (Gjerdrum Pedersen et al., 2011:77).

\section{Methods}

The basic purpose of this research is to identify and examine the implementation of diversity management contents into the curricula of higher education institutions in countries of the Western Balkans.
The research is based on the quantitative method of descriptive non-experimental method of empirical pedagogical research. The absolute and relative values, and the average scores on the attitude scales have been calculated. The technique used to collect data was a questionnaire, which had been purposely created for the needs of our study, based on the researched theoretical premises of various professional and scientific literature. The first part of the questionnaire gathered basic demographic data about the higher education teachers employed at colleges and faculties in the Western Balkan countries. The second part of the questionnaire consisted of three scales. The dimensions of diversity scale examined how the higher education teachers discuss the dimensions of diversity with students. The objectives in teaching diversity scale united the importance of objectives that examine the extent of the teachers' help when teaching students about diversity. The barriers scale examined how the higher education teachers identify barriers to the development 
of diversity management contents in their higher education institution. The Cronbach alpha reliability coefficients in this study amounted to $\alpha=0.848$ for validating the dimensions of diversity, $\alpha=0.841$ for the objectives in teaching diversity, and $\alpha=0.839$ for the barriers to the development of diversity management contents. According to George and Mallery (2006), such reliability is good. The data was processed using the SPSS 19.0 statistical software package.

The study encompassed 1560 members of the pedagogical staff of colleges and faculties in countries of the Western Balkan, of whom $63 \%$ were women and $37 \%$ were men. Of the mentioned respondents, $24 \%$ are assistant professors, $21 \%$ are teaching assistants, $18 \%$ are associate professors, $15 \%$ are full professors, $12 \%$ are lecturers, $9 \%$ are senior lecturers, and $1 \%$ is foreign language teachers. $25 \%$ are employed at colleges and $75 \%$ at faculties. The majority, 47\%, have been employed in the higher education sector up to 10 years, $30 \%$ from 11 to 20 years, $15 \%$ from 21 to 30 years, $6 \%$ from 31 to 40 years, and $2 \%$ for at least 41 years. Most of the respondents were from Serbia (35\%), followed by Slo- venia and Bosnia and Herzegovina (18\%), Croatia (13\%), Macedonia (9\%) and Montenegro (7\%).

The basic limitation of this study is that the results cannot be generalised to the entire population of higher education teachers who are employed at colleges and faculties in the Western Balkan countries, since it would have to be expanded to cover a larger number of respondents.

\section{Results}

Diversity management includes promoting the development of culture, values and relationships within society, a positive assessment of diversity, and making use of its advantages. Globalisation, demographic, economic and social trends in all countries of the Western Balkans are increasing the diversity of the active population, which presents a challenge for higher education institutions, since, in addition to educating students, their mission is to teach students to understand and accept equality assurance and prevention of discrimination with regard to gender, race, age, ethnic affiliation, sexual orientation, etc. In light of this fact, we were interested in

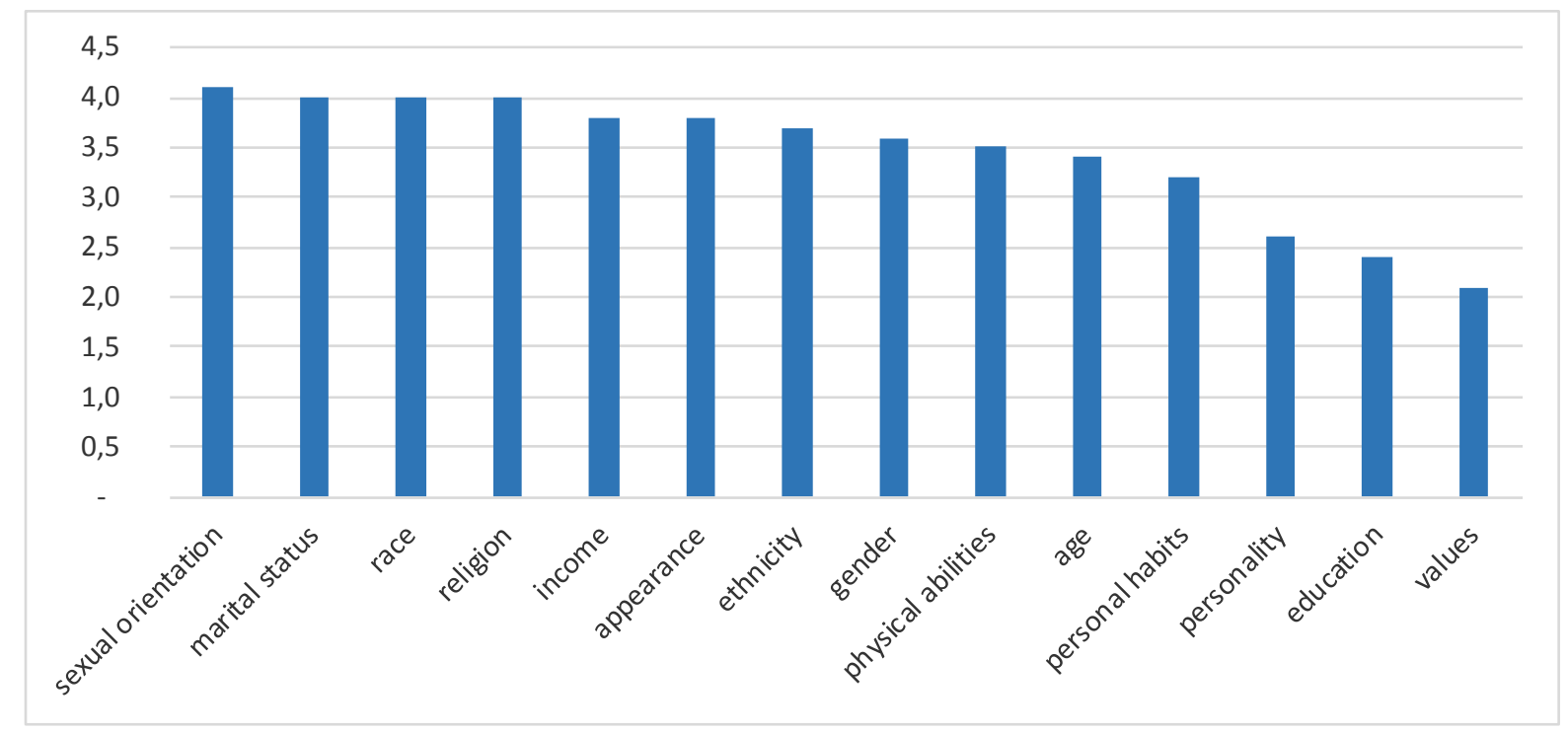

Graph 1. Frequency of discussing the dimensions of diversity with students. 
how often the pedagogical staff discusses the dimensions of diversity with their students. Individual dimensions were evaluated with a Likert-type attitude scale with the following items: 1 - never, 2 - rarely, 3 - sometimes, 4 - often and 5 - very often.

Graph 1 shows that the things the pedagogical staff most often discuss with their students are sexual orientation $(\mathrm{M}=4.1)$, marital status $(\mathrm{M}=$ $4.0)$, race $(M=4.0)$, and religion $(M=4.0)$. This is followed by discussions about income and appearance $(M=3.8)$, ethnicity $(M=3.7)$, gender $(M=$ 3.6), physical abilities $(M=3.5)$, age $(M=3.4)$, and personal habits $(\mathrm{M}=3.2)$. They spend less time discussing personality $(\mathrm{M}=2.6)$, the level of education $(\mathrm{M}=2.4)$, and values $(\mathrm{M}=2.1)$.

The pedagogical staff was also asked which types of diversity had been implemented into the contents of the courses they are teaching, and which types of diversity they should be teaching students about, regardless of their study course. Diversity issues addressed in teaching were evaluated with scale with the following items: 1 - no, 2 - partially and 3 - yes. Graph 2 shows that higher education institu- tions have implemented some of the diversity factors into the contents of the courses they are teaching. The curricula of their courses enable the surveyed members of the pedagogical staff to discuss the following with their students: level of education (70\%); values (68\%); different personalities (52\%); personal habits (44\%); physical abilities (33\%); gender differences (31\%); age differences (31\%); income (30\%); ethnic affiliation (27\%); differences among races and religions (19\%); importance of appearance (18\%); views on marital status (16\%); and sexual orientation (only 12\%).

They also feel that, regardless of their study course, students should be taught how to understand diversity and be given the opportunity to familiarise themselves with the importance of integrating diversity into everyday life. They propose that the following dimensions of diversity be addressed more: values (95\%), personality $(85 \%)$, level of education (85\%), physical abilities (59\%), personal habits (58\%), ethnic affiliation $(46 \%)$, age $(44 \%)$, gender $(42 \%)$, income $(41 \%)$, race $(38 \%)$, religion $(35 \%)$, appearance $(34 \%)$, sexual orientation (33\%), and marital status (26\%) (Graph 3).

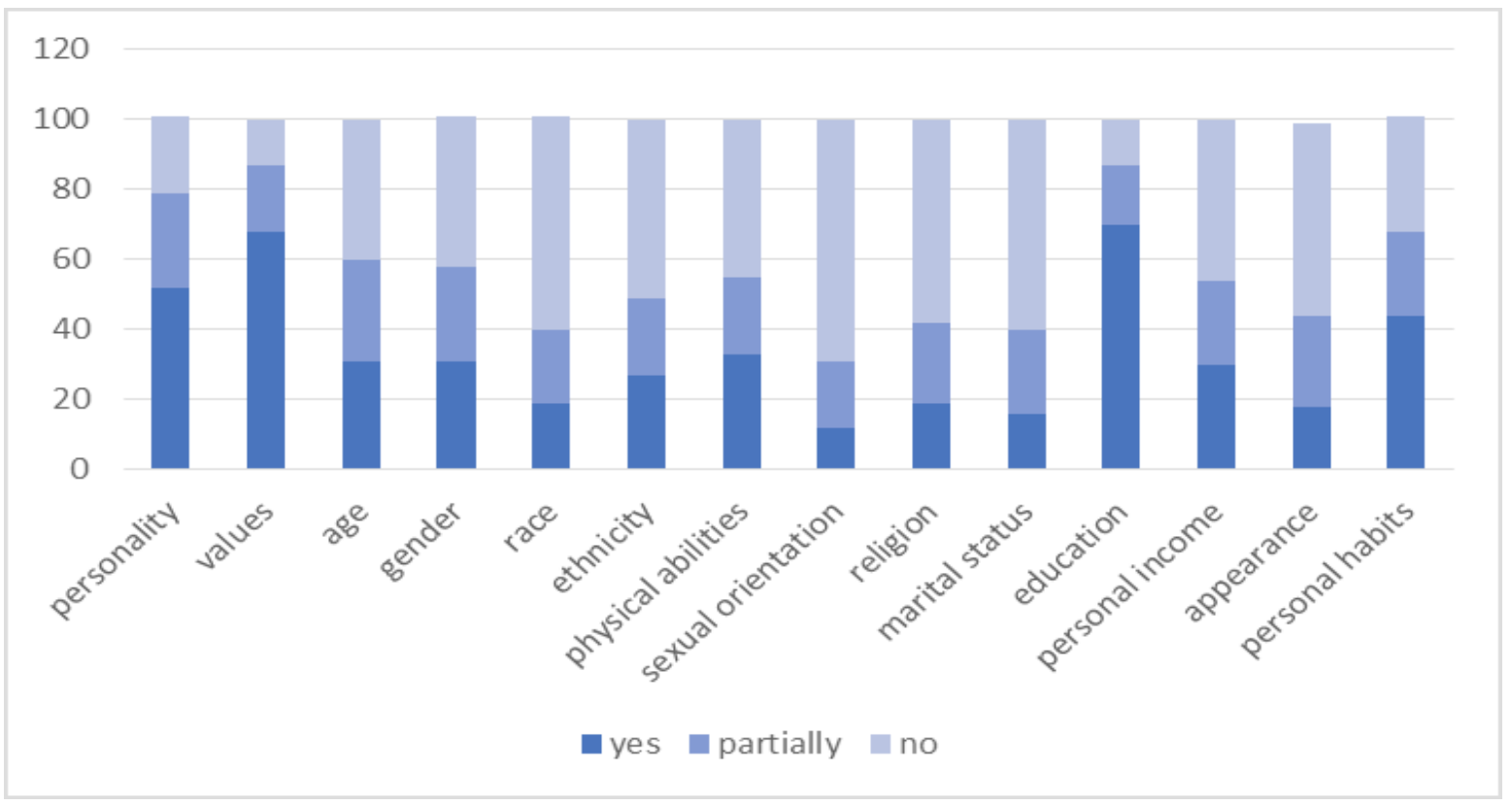

Graph 2. Diversity issues addressed in teaching. 


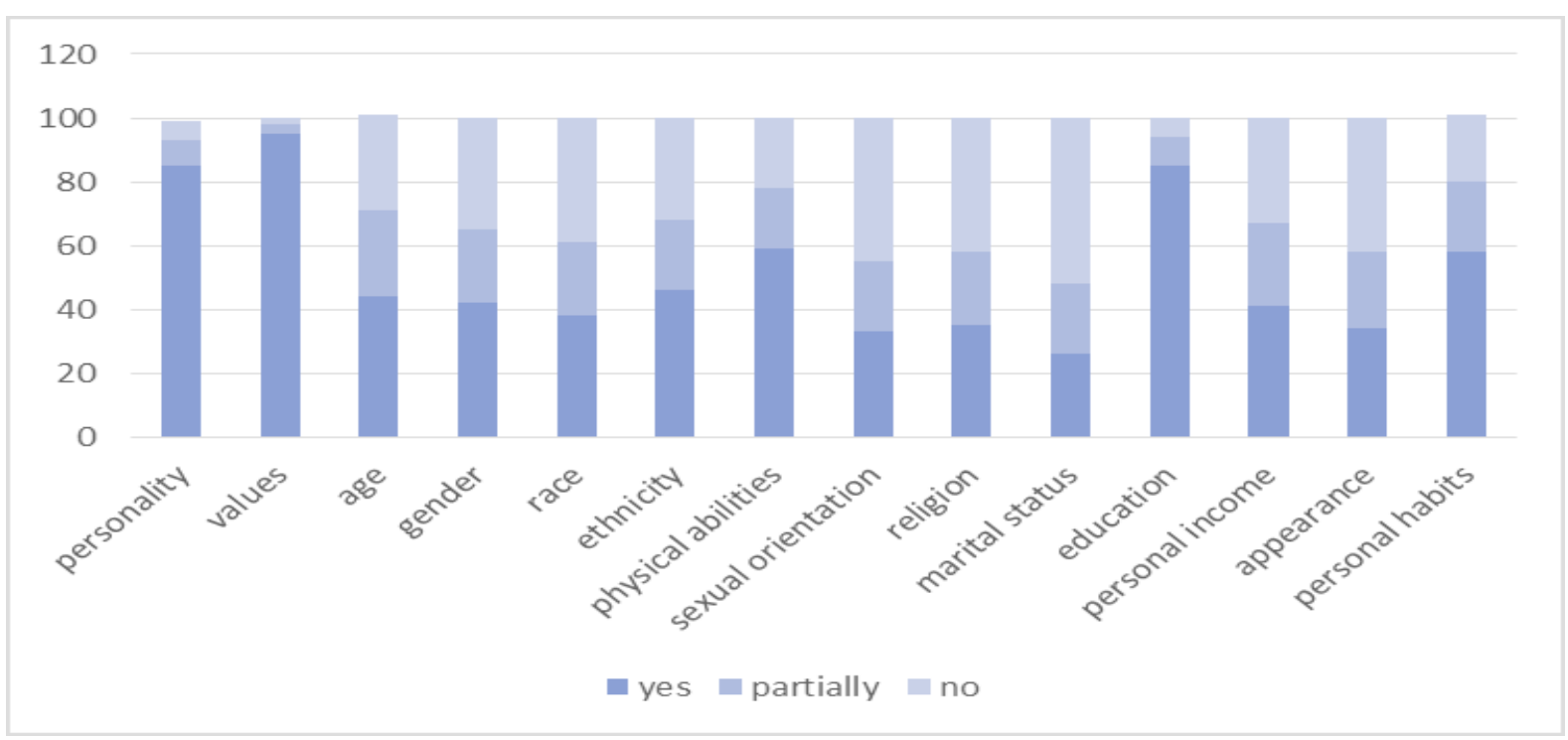

Graph 3. Diversity issues which should be addressed in teaching.

Afterwards, we were interested in which methods they thought were most appropriate for teaching diversity management (Graph 4).

The results from the survey show that the discussion method (79\%) and case method (79\%) remain the most popular teaching methods when it

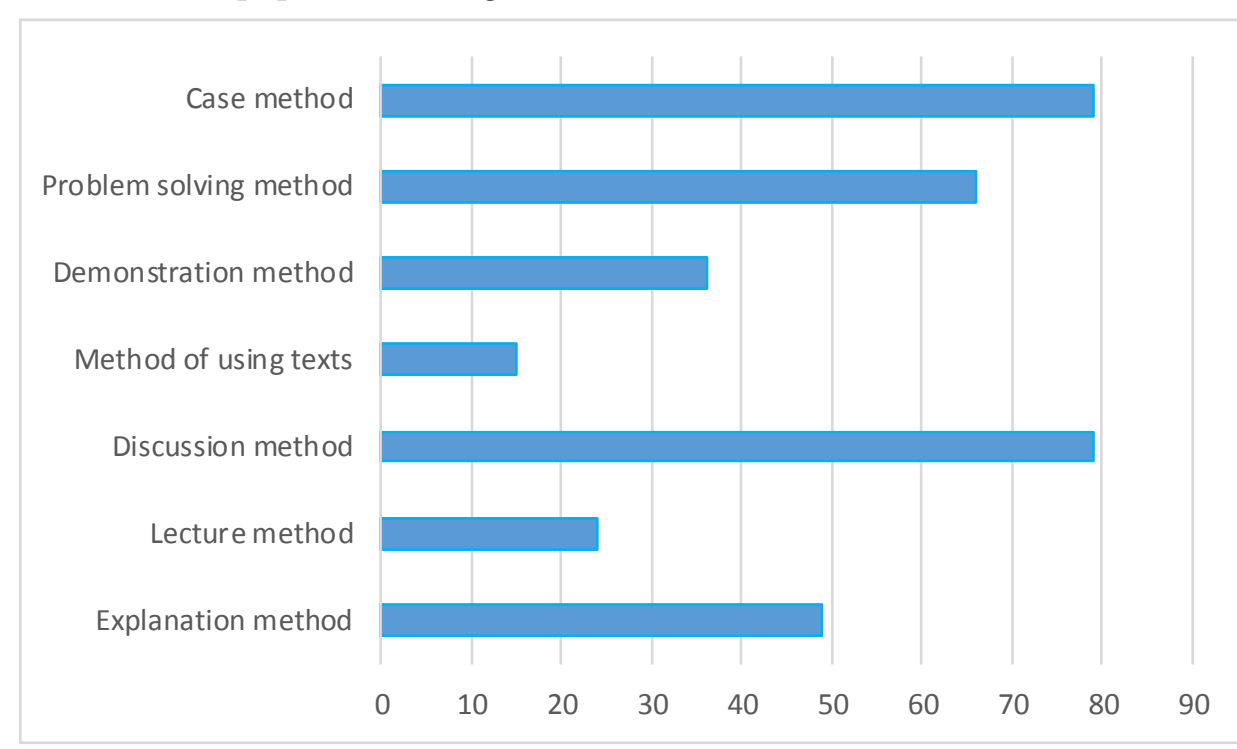

Graph 4. Methods for diversity management teaching. comes to diversity management. They are followed by the problem-solving method (66\%), the explanation method (49\%), the demonstration method (36\%), the lecture method (24\%), and the method of using texts (15\%). In our opinion, the resources for diversity management teaching are largely developed internally, probably because of the lack of specific manuals and materials. However, college and faculty teachers are taking steps to develop new and innovative ways of teaching diversity management issues.

We also wanted to find out which learning objectives were important when teaching students about diversity. Individual objectives were evaluated with a Likert-type attitude scale with the following items: $1-$ never, 2 


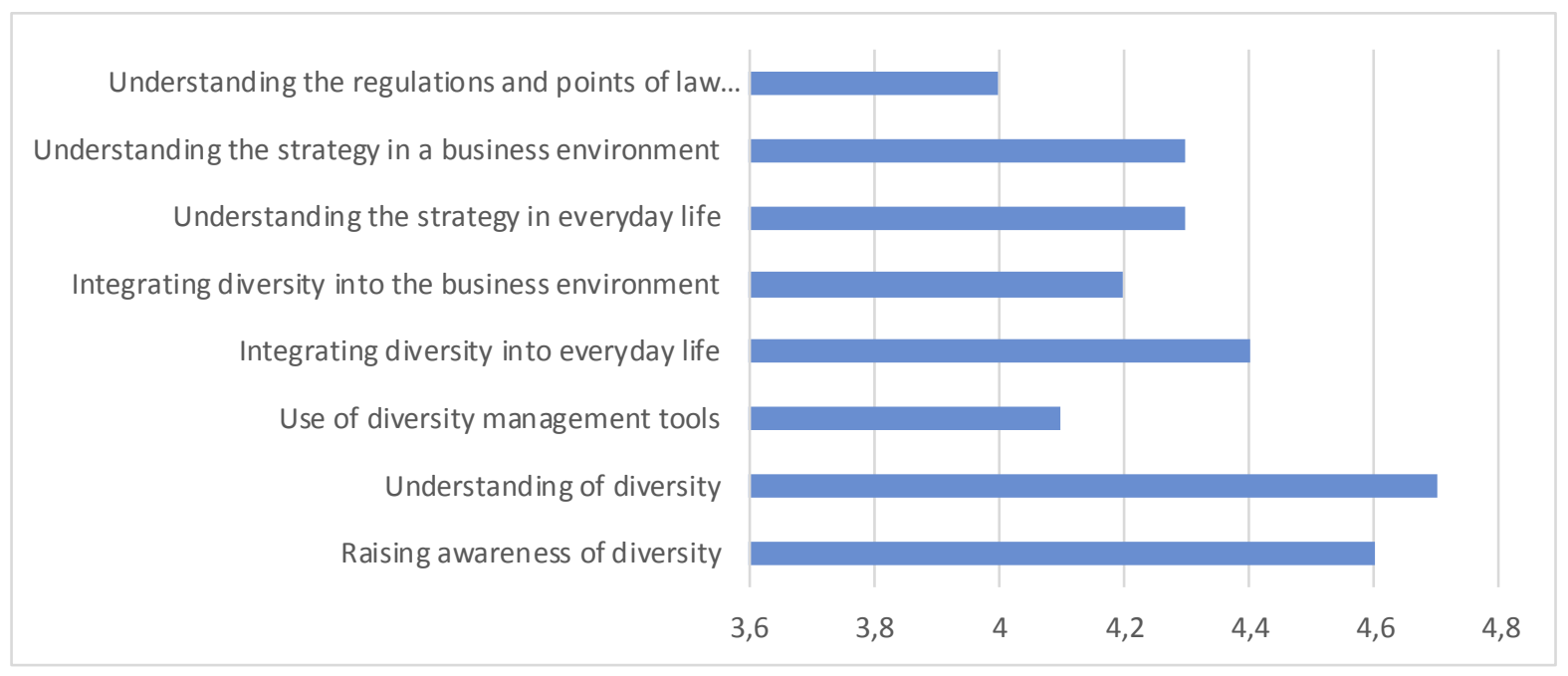

Graph 5. Importance of objectives in teaching diversity.

- rarely, 3 - sometimes, 4 - often and 5 - very often. The pedagogical staff rated the objectives very high (Graph 5).

As the most important learning objective, the pedagogical staff pointed out the understanding of diversity $(\mathrm{M}=4.7)$ and raising awareness of diversity $(M=4.6)$. These were followed by teaching how to integrate diversity into everyday life $(M=4.4)$; knowledge about and understanding of the role and importance of a diversity management strategy in everyday life $(M=4.3)$; knowledge about and understanding of the role and importance of a diversity management strategy in a business environment ( $M$ $=4.3$ ); teaching how to integrate diversity into the

No incentive at the national level

No incentive at the local level

No interest in the national policy for the development of education

No interest from the Ministry of Education

No interest among students

Teachers' lack of knowledge about diversity management

No interest among employed teachers

No interest from the faculty/college

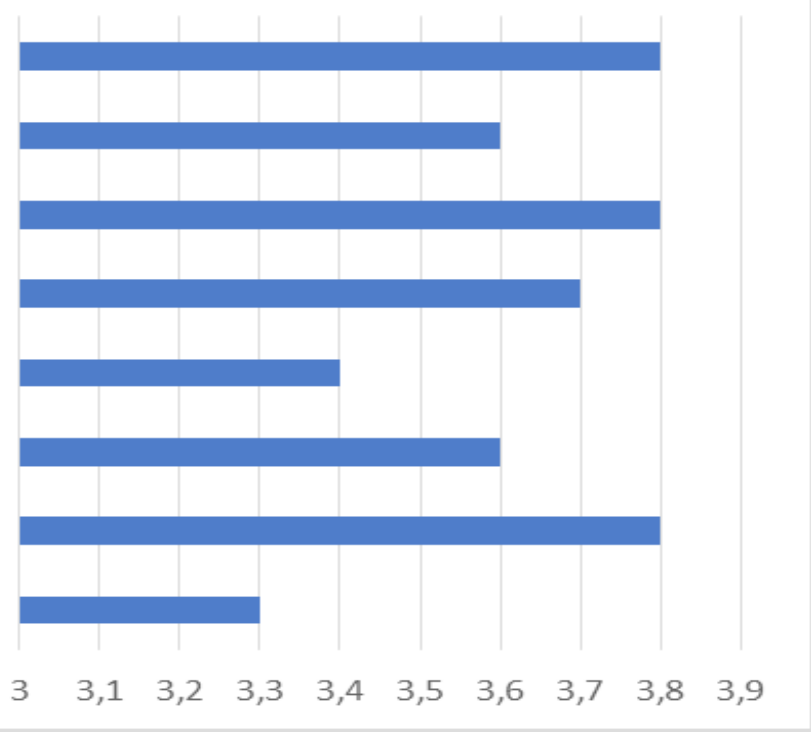

Graph 6. Barriers to the development of diversity management contents. 
planning and implementing of business decisions in a business environment $(M=4.2)$; use of diversity management tools $(\mathrm{M}=4.1)$; and understanding the regulations and points of law regarding diversity $(\mathrm{M}$ $=4.0$ ).

We were also interested in what they thought were barriers to the development of diversity management contents in their higher education institution (Graph 6). Individual objectives were evaluated with a Likert-type attitude scale with the following items: 1 - very insignificant barrier, 2 - insignificant barrier, 3 - partly important barrier, 4 - an important barrier and 5 - a very important barrier

The pedagogical staff think that the biggest barrier to the development of diversity management contents is the teachers, who are not interested enough in developing diversity management contents $(\mathrm{M}=3.8)$; followed by little incentive at the national level $(M=3.8)$, since diversity management contents have not been included in the national higher education policy $(\mathrm{M}=3.8)$. They also identified the Ministry of Education's lack of interest $(\mathrm{M}=$ 3.7) and the teachers' lack of knowledge about diversity management as barriers $(\mathrm{M}=3.6)$.
They viewed the management of faculties and colleges as the smallest barrier; we were hence interested in whether the strategy of their educational institutions focused on diversity management: $31 \%$ of the educational institutions did focus on it; $45 \%$ did not; $21 \%$ planned it for the near future; and $3 \%$ of the educational institutions did not plan it for the near future Graph 7).

Among those higher education institutions which are planning to implement diversity management into their operation, the pedagogical staff have information that $69 \%$ will integrate diversity management contents into their vision, mission and/or strategy; $56 \%$ into the rules laying down the rights and obligations of students; $54 \%$ into scientific and research work; $48 \%$ into their internal acts laying down the rights and obligations of employees; $46 \%$ into the curricula of some of the compulsory courses; $41 \%$ into the curricula of elective courses; $34 \%$ into the curricula of modules; $30 \%$ into the hiring of new employees; and $21 \%$ into the partial study programmes (Graph 8).

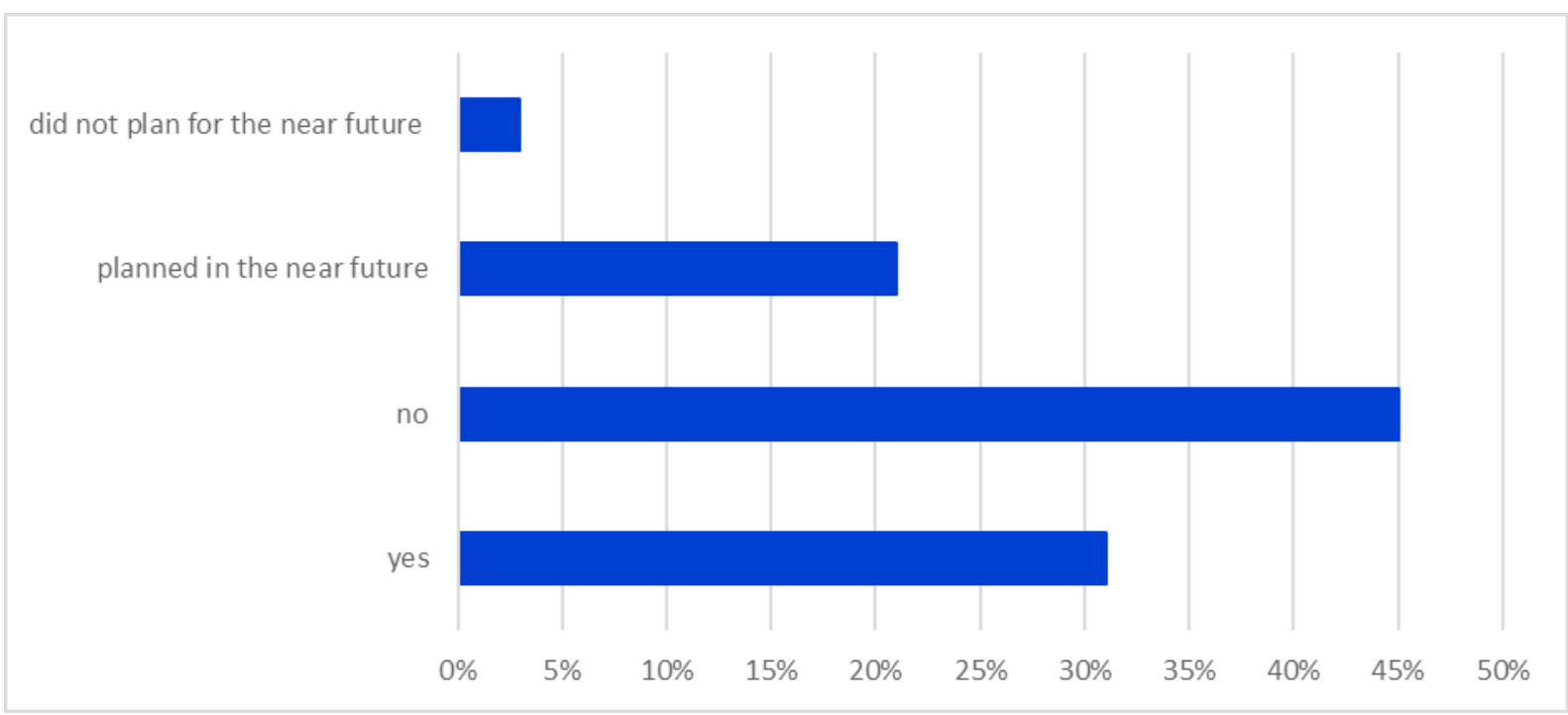

Graph 7. The strategy of educational institutions focused on diversity management. 


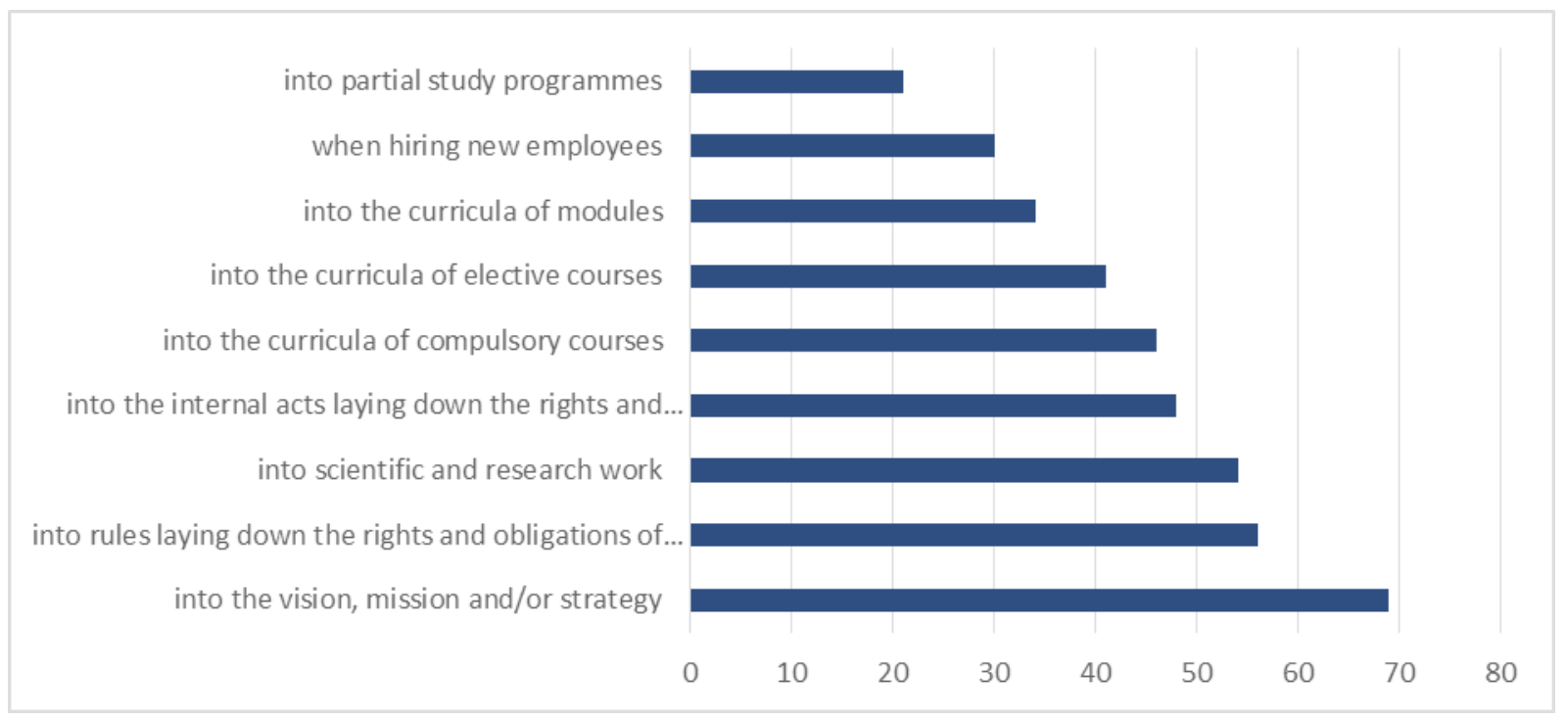

Graph 8. Implementation of diversity management into the future operation of institutions.

\section{Discussion and Conclusion}

Today, diversity management is more important than ever. Differences in national culture, ethnic origin, religion and so forth raise important questions of how to manage these issues in societies. In addition, some societies are facing problems with an ageing population and all have to deal with issues in relation to gender, disability, etc. Realising that diversity issues are here to stay, colleges and faculties need to take meaningful actions to include diversity issues in both teaching, research, student affairs and employment practices (Gjerdrum Pedersen et al., 2011). The present research study has reached a similar conclusion, since the strategies of $52 \%$ of colleges and faculties already focus on diversity management or plan such activities in the near future.

An important consequence, which the concept of diversity has brought about, is that diversity is obviously a critical issue for society. The emerging stream of critical diversity studies calls attention to unequal power relations in society and the need for change that is inextricable from issues of diversity at colleges and faculties (Prasad and Mills, 1997; Jones et al., 2000; Litvin, 2006; Zanoni et al., 2010;
Benschop, 2011). Since higher education teachers are also aware of this, they are trying to discuss this issue with their students as much as possible, in accordance with their (lack of) knowledge about the contents and tools of diversity management, regardless of the extent to which the dimensions of diversity have been implemented into the curricula of their courses. They most often discuss sexual orientation $(\mathrm{M}=4.1)$, as it is currently one of the most burning issues which individual countries of the Western Balkans are trying to handle as non-discriminatively as possible. Teachers spend too little time talking with their students about values $(M=2.1)$, which are very important, for they direct the students' way of thinking, judging, deciding, acting and behaving towards other (different, diverse) people and the environment, based on information obtained from their surroundings.

In line with the larger literature on critical management studies, critical diversity studies address inequalities in the control of resources, structures, behaviours, agendas, ideologies and cultures (Karreman and Alvesson, 2009). Within critical diversity studies, researchers investigate current practices of dealing with difference and heterogeneity, 
and subsequently identify fruitful ways to change these practices and diminish inequalities in society. Higher education institutions can likewise aspire to this, using suitable approaches - raising awareness of diversity, teaching about the importance of integrating diversity and of knowledge about and understanding of the role and importance of a diversity management strategy in everyday life and in a business environment - to have a positive impact on the feelings of students and higher education teachers, on the atmosphere among them, and on a better public image or reputation. Kosi et al. (2012) mention some of the advantages brought about by diversity and its effective management: a comfortable working environment, higher morale and satisfaction, improvement in relationships among different groups of employees and students, and an increase in employee productivity and in students' academic achievement.

It is very important that the pedagogical staff realise that diversity is a broad concept, which encompasses many aspects of differentness or personal circumstances among people and affects how individuals, i.e. students, behave and how they interact (West-Burnham, 2010). It is important that they draw the attention of students to the fact that some groups of people have not yet been equally integrated into the existing society and are still not equal in the eyes of the law in all areas of social life, which is discriminative and in violation of social justice. For this reason, higher education teachers propose that students be taught values, regardless of their study course, and that teachers talk with them about respecting different types of personalities, as the latter have a distinct impact on an individual's self-image.
The responses of the surveyed higher education teachers indicate that the biggest barrier to the development and discussion of diversity management contents lies in the teachers themselves $(\mathrm{M}=3.8)$. It would therefore be sensible to organise training programmes for teachers that would raise awareness and promote the understanding of cultural, social and economic backgrounds of individuals, and of their abilities, lifestyles and interests, and training on sensitivity towards differences in behaviour, comprehension and feelings among the teachers themselves and among them and their students. Only informed teachers can have an educational reaction to potential discriminative behaviour of their students.

So far, no research has been conducted on diversity management in the higher education sector in the Western Balkans, so our results cannot be compared with the results of other studies; however, they can serve as an opportunity and scientific basis for further research. Diversity management benefits teachers at colleges and faculties by creating a fair and safe environment, in which opportunities are accessible to all. The tools for the management of a diverse society should be used for educating students about diversity and the issues related to it, including knowledge about laws and regulations. The majority of regions and countries are made up of different cultures, which is why colleges and faculties must learn how to adapt to this in order to be successful. The long-term success or failure in teaching diversity management will determine how they will be able to manage diversity in the future.

\section{References}

- Anko, B. et al. (2007). Temeljno usposabljanje za trajnostni razvoj. Ljubljana: Andragoški center Republike Slovenije.

- Aronowitz, S. \& Giroux, A. (1991). Postmodern Education: Politics, Culture and Social Criticism. Minnesota: Minnesota Press. 
- Bâc, D. P. (2008). Sustainable Development - A Theoretical Approach. Oradea Journal of Business and Economics. Retrieved from www: http://steconomiceuoradea.ro/anale/volume/2008/v2-economy-and-business-administration/102.pdf.

- Benschop, Y. (2011). The Dubious Power of Diversity Management. In: Gröschl, S. (Ed.). Diversity in the Workplace: Multi-disciplinary and International Perspectives (14-28). Farnham, Surrey, Burlington: Gower Publishing Limited.

- Blenker, P., Dreisler, P. \& Kjeldsen, J. (2006). Entrepreneurship Education - the New Challenge Facing the Universities. Aarhus: Aarhus School of Business.

- Bushholtz, A. K. \& Carroll, A. B. (2009). Business and Society: Ethics and Stakeholder Management. Mason: Cengage Learning.

- Casse, P. (2016). Voditeljstvo z raznolikostjo v mislih: Imamo izbiro?. HRM. 4, 6-7.

- Cortese, A.D. (2003). The critical role of higher education in creating a sustainable future. Planning for Higher Education. Issuse 31 (3), 15-22. Retrieved from www: https://scup-framework-production.s3.amazonaws. com/cms/asset_version/file/04/84/48483.pdf?AWSAccessKeyId=AKIAJYNXXDGIQEC64CEQ\&Expires=1479076511\&Signature $=r x 3 r 8 n s F 1$ acxCDd2F4X2M85zPSI\%3D\&response-content - disposition $=$ inline $\%$ 3B\%20filename\%3D\%22 cortese.pdf\%22\&response-content-type=application $\% 2$ Fpdf.

- Gardenswartz, L. \& Rowe, A. (2003). Diverse Teams at Work: Capitalizing on the Power of Diversity. Alexandria, Virginia: Society for Human Resource Management.

- George, D \& Mallery, P. (2006). SPSS for Windows Step by Step. A Simple Guide and Reference. 13.0 Update. Boston: Pearson.

- Gjerdrum Pedersen, E .R., Sánchez Gardey, G. \& Tywuschik, S. (2011). Diversity Management at Business Schools and Universities: How Do We Change Tomorrow's Managers? In: Gröschl, S. (Ed.). Diversity in the Workplace: Multi-disciplinary and International Perspectives (63-78) Farnham, Surrey, Burlington: Gower Publishing Limited.

- Glavič, P. \& Kovačič Lukman, R. (2007). Review of sustainability terms and their definitions. Journal of cleaner production. 15 (18), 1875-1885.

- Greif, T. (2009). Upravljanje raznolikosti v zaposlovanju: smernice za delodajalce in sindikate. Ljubljana: Društvo Škuc.

- Harzing, A. W. \& Pinnington, A. H. (2011). International Human Resource Management. Los Angeles, London, New Delhi, Singapore, Washington DC: Sage.

- Johnson, B. (2016). Kulturna inteligentnost za raznolika delovna okolja. HRM. 4, 65-67.

- Jonsen, K. et al. (2011). Diversity - A Strategic Issue?, In: Gröschl, S. (Ed.). Diversity in the Workplace: Multidisciplinary and International Perspectives (29-55). Farnham, Surrey, Burlington: Gower Publishing Limited.

- Jurić, V. (2005). Kurikulum suvremene škole. Pedagogijska istraživanja. 2, 185-197.

- Kosi, T. et al. (2012). Upravljanje raznolikosti v slovenskih in tujih podjetjih. Koper: Založba Univerze na Primorskem.

- Košak, A. (2010). Enakost in pravičnost v izobraževanju otrok v osnovni šoli. In: Peček, P (Ed.). Izzivi vodenja za raznolikost, Zbornik 14. Strokovnega posveta Vodenje v vzgoji in izobraževanju (11-19). Kranj: Šola za ravnatelje. 
- Ličen, N. (2015). Trajnostni razvoj: od teorije k praksi v izobraževanju odraslih. Pospeševanje globalnega razvojnega modela kot izhodišče za načrtovanje zelenih izobraževalnih programov. Ajdovščina: Ljudska univerza.

- Litvin, D. (2006). Diversity: Making space for a better case. In: Konrad, A. M. et al. (Eds.). Handbook of Workplace Diversity (75-94). London: Sage.

- Milharčič Hladnik, M. (2003). Bogastvo konceptualizacij in analiz šolske uspešnosti. In: Razdevšek Pučko, C. (Ed.). Uspešnost in pravičnost v šoli (99-116). Ljubljana: Pedagoška fakulteta.

- Nemec, V. (2005). Kako do uspešnega menedžmenta. Ljubljana: Modrijan.

- Peček, M. \& Lesar, I. (2006). Pravičnost slovenske šole: mit ali realnost. Ljubljana: Sophia.

- Plascha, G. R. \& Welsch, H. P. (1990). Emerging Structures in Entrepreneurship Education: Curricular Designs and Strategies. Entrepreneurship: Theory and Practice. 3, 55-71.

- Pont, B., Nusche, D. \& Hopkins, D. (2008). Improving school leadership. Pariz: OECD.

- Prasad, P. \& Mills, A. J. (1997). From Showcase to Shadow: Understanding the Dilemmas of Managing Workplace Diversity, In: Prasad, P. (Ed.). Managing the Organizational Melting Pot: Dilemmas of Workplace Diversity (3-27). London: Sage.

- Previšić, V. (2005). Kurikulum suvremenog odgoja i škole: metodologija i struktura. Pedagogijska istraživanja. 2, 165-173.

- Rozman, a. (2016). Kako izkoristiti potencial raznolikih timov. HRM. 4, 16-19.

- Wangare Wambui, T. et al (2013). Managing Workplace Diversity: A Kenyan Perspective. International Journal of Business and Social Science. 4 (16), 199-218.

- West_Burnham, J. (2010). Vodenje za raznolikost: zagotavljanje enakosti, vključenosti in socialne pravičnosti. Vodenje v vzgoji in izobraževanju. 1, 7-16.

- Wright, T. (2006). The Evolution of Sustainability Declarations in Higher Education. In: Corcoran, P. B. \& Wals, A. E. J. (Eds.). Higher Education and the Challenge of Sustainability. Dordrecht: Kluwer Academic Publishers.

- Zanoni, P. et al. (2010). Unpacking Diversity, Grasping Inequality: Rethinking Difference through Critical Perspectives. Organization. 17 (1), 9-29. 


\section{Јасмина М. Старц}

Факултет за пословне и управне науке, Ново Место, Словенија

\section{Имплементација садржаја управљања разноликошћу у наставне планове високошколских установа у земљама Западног Балкана}

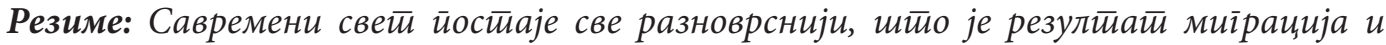

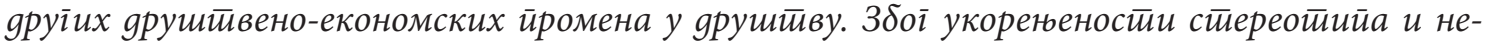

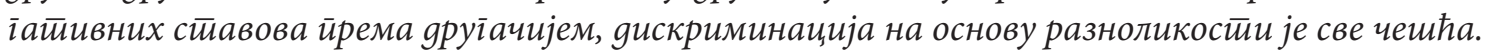

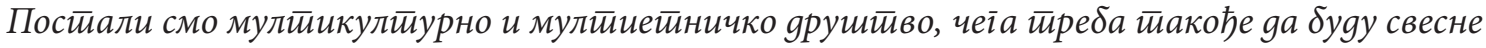

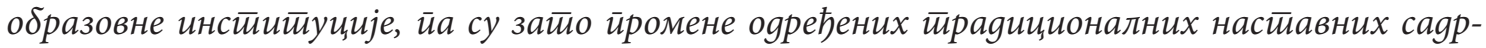

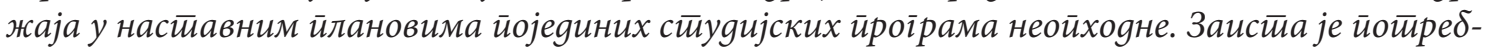

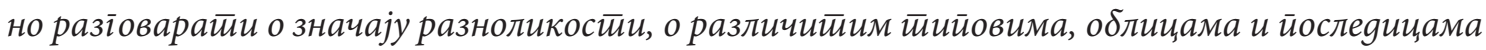

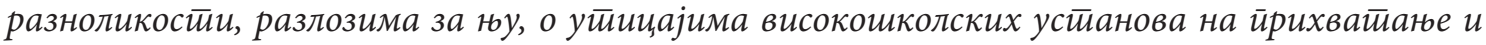

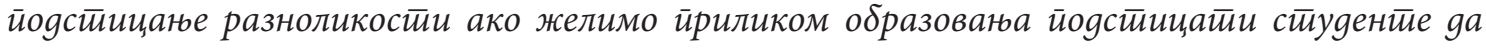

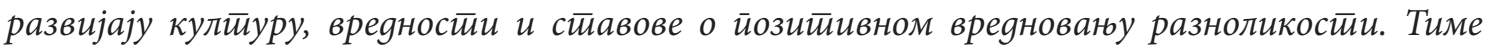

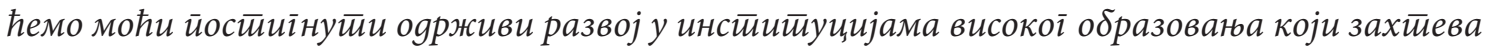

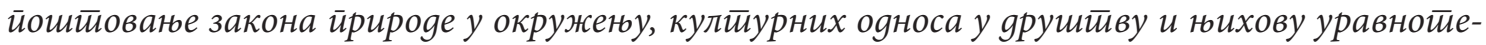
жености, јер образоване за оярживи развој мотивише, обезбеђује знане, стивара нове йуйеве gо йравеgнијеі и равнойравноі светиа, омоїућава иромену разумевана живойне среgине,

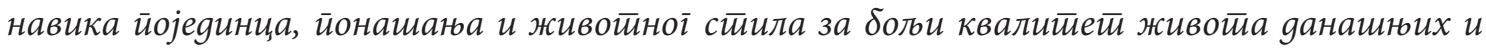

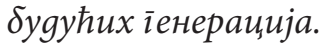

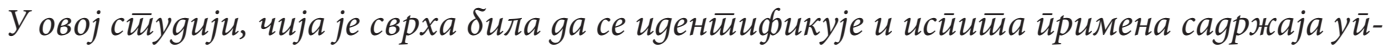
равльаға разноликошћу у насииавном йлану високошколских устианова у землама Зайаgної

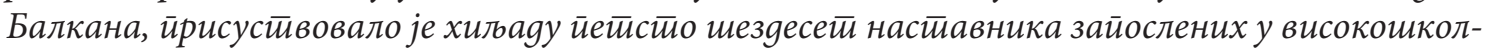
ским устиановама Зайаgноі Балкана. Међу юима је 24\% доценайа, 21\% асистиенайа, 18\% ванреgних ӥрофесора, 15\% реgовних ӣрофесора, 12\% ирреgавача, 9\% виших ирреgавача и 1\% лекйора. Њих 25\% зайослено је на високим иколама и 75\% на факулиетиима. Највише юих,

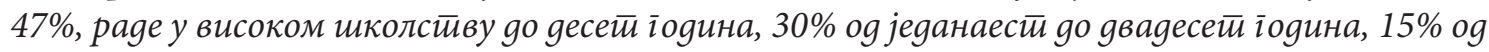

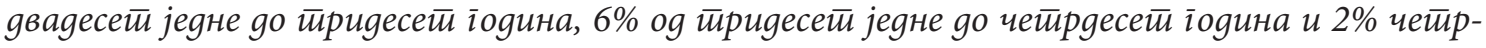
gесей јеgну іодину или више. Већина исиитианика је из Србије (35\%), затиим из Словеније и Босне и Хериеі̄овине (18\%), Хрвайске (13\%), Макеgоније (9\%) и Црне Горе (7\%).

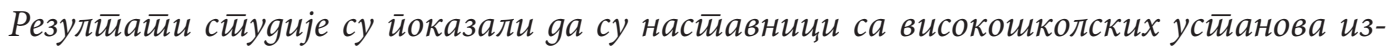
међу димензија разноликостии у настиавним йлановима ӣреgметиа које йреgају обухватиили

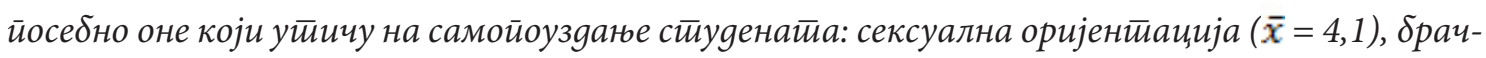

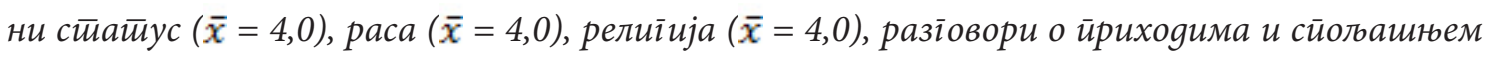

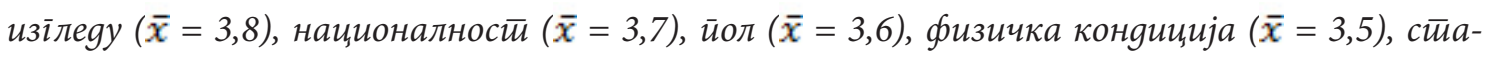

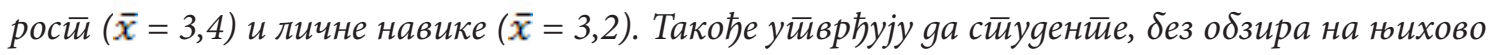

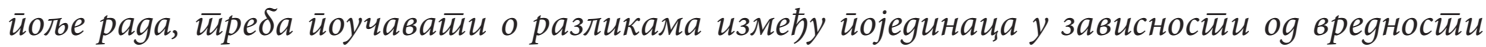
(95\%), тичности (85\%), образована (85\%), физичке кондииије (59\%), личних навика (58\%), ейничке йрийаgностии (46\%), сииаростии (44\%), йола (42\%), йрихоgа (41\%), расе (38\%), верске 


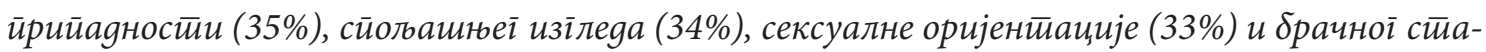

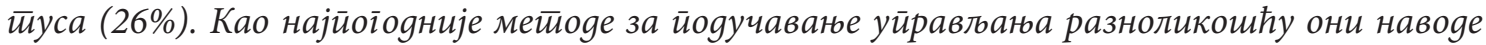
мет̄оgу случаја (79\%), метиоgу разіовора (78\%) и ирроблемску метиоgу (66\%). Међу најважнијим настиавним изиљевима ӣриликом иооучаваюа разноликошћу они су изложили разуме-

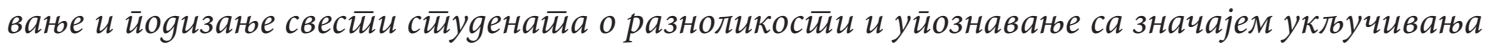

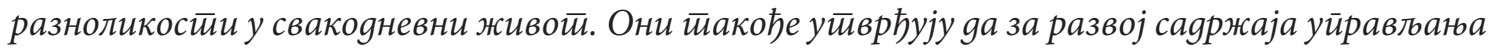

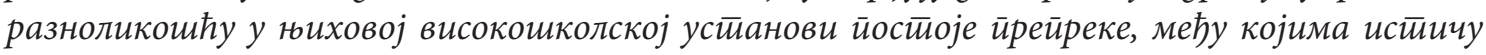
насииавнике који немају довољно иниеересоваю а за развој саяржаја уйрављањ а разноликошћу

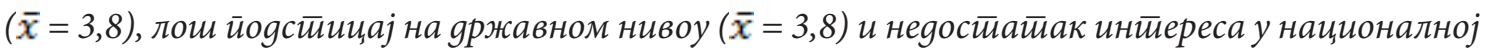

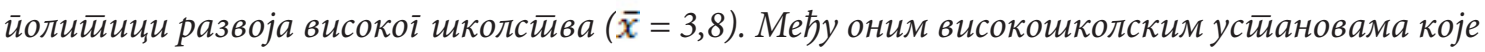
йланирају gа сировеgу уиравльане разноликошћу у функиионисаюе високошколске усиианове, 69\% юих ће саяржаје уйрављьюь а разноликошћу gа укључи у визију, мисију и/или ситратиеіију,

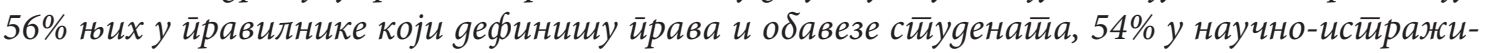

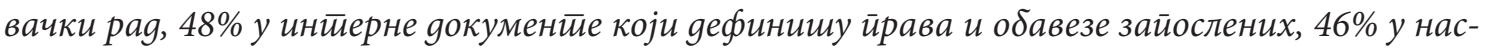
йавне йланове йојеgиних обавезних йреgметй, 41\% у научне йланове изборних ирреgметиа и 34\% у научне йланове ирреgметиа модула.

Уӣрављаюе разноликошћу користии настиавницима на високим школама и факулиие-

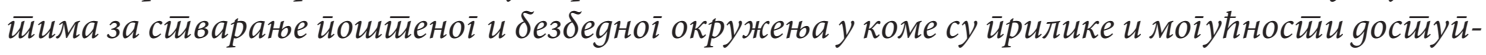

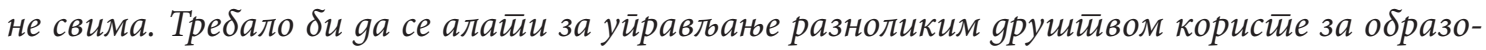

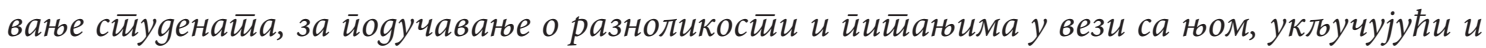
йознаваюе закона и йройиса. У већини реїиона и земаља коеїзистиира више различи-

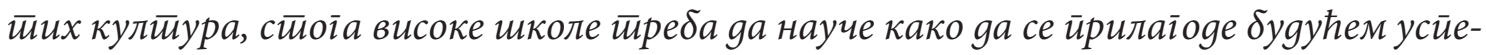
ху у уйрављаюь разноликошћу. Дуїорочни усиеех или неусиех у йоучаваюу уйрављань разноликошћу уйврgиће се на начин који ће йоказайи gа ли су усиетли gа уйрављьју разноликошћу у буgућностич.

Клучне речи: иоучаваюе уйрављана разноликошћу, високошколске усиианове, одржи-

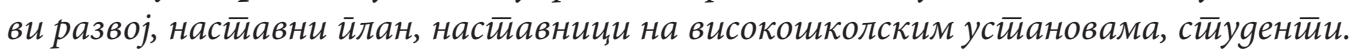

